\title{
Brain Microvessel Endothelial Cells in Tissue Culture: A Model for Study of Blood-Brain Barrier Permeability
}

\author{
Phillip D. Bowman, PhD,* Steven R. Ennis, PhD, ${ }^{*}$ Kyle E. Rarey, PhD, $†$ \\ A. Lorris Betz, $\mathrm{MD}, \mathrm{PhD},{ }^{*}$ and Gary W. Goldstein, $\mathrm{MD}^{*}$
}

Endothelial cells were prepared from bovine brain microvessels and grown in tissue culture. They contained factor VIII/von Willebrand antigen, the most specific marker available for determination of the endothelial origin of cells in culture. The cultured cells formed complex tight junctions and contained few pinocytotic vessels. These properties are responsible for formation of the blood-brain barrier in vivo. When monolayers of the endothelial cells were exposed briefly to a calcium-free solution or treated with $1.6 \mathrm{M}$ arabinose, distinctive morphological changes occurred in the intercellular contacts. In either case, a normal structure was reestablished following return to control medium. To assess the effect of these treatments on transcellular permeability, we measured the movement of sucrose labeled with carbon 14 across a monolayer of endothelial cells cultured on a collagen-coated nylon mesh. Removal of external calcium increased the rate of sucrose movement by $120 \%$; the arabinose treatment increased transcellular flux by $40 \%$.

Bowman PD, Ennis SR, Rarey KE, Betz AL, Goldstein GW: Brain microvessel endothelial cells in tissue culture: a model for study of blood-brain barrier permeability. Ann Neurol 14:396-402, 1983

Defects in brain microvessel function occur in a wide variety of neurological diseases. The resulting breakdown of the blood-brain barrier may produce edema and result in further brain injury from increased intracranial pressure or inadequate tissue perfusion. The cellular mechanisms responsible for such changes in brain microvessel permeability are not well understood.

Under normal conditions the endothelial cells in brain microvessels are sealed together by continuous tight junctions that limit the movement of polar molecules across the vessel wall [18]. In addition, the endothelial cells contain only a few pinocytotic vesicles, and these do not appear to carry material across the cell from lumen to interstitial fuid [4]. After injury caused by acute hypertension [23] or ischemia [15], more pinocytotic vesicles are found in the endothelial cells, and these are thought to act as a carrier system to transfer plasma into the brain. Alternately, separation of tight junctions between endothelial cells may provide a paracellular pathway for the abnormal movement of plasma constituents into brain. Changes in tight junction permeability are reported after infusion of hypertonic solutions through the cerebrovascular bed [17].

To study formation and disruption of the barrier in more detail, we developed a method to isolate microvessels from bovine brain and then release and grow the endothelial cells in tissue culture. The cultured cells contain factor VIII/von Willebrand antigen (FVIII/ vWF-AG), the most specific marker for endothelial cells. Ultrastructural examination revealed frequent tight junctional complexes and few pinocytotic vesicles, suggesting a resemblance of the cultured cells to their in vivo counterpart. Alterations in the integrity of this in vitro barrier were produced by removal of extracellular calcium or treatment with high concentrations of arabinose and studied by histological observation and measurement of transcellular tracer movement across a monolayer of the endothelial cells grown on a collagencoated nylon mesh. A portion of this work appeared in a preliminary report [7].

\section{Methods}

Isolation of Microvessels and Culture of Endotbelial Cells Endothelial cell cultures were prepared by a modification of our previously described method for rat brain [1]. The tissue culture medium used for cell isolation consisted of minimal essential media (MEM; GIBCO, Grand Island, NY) with 50 $\mathrm{mM}$ Hepes buffer $(\mathrm{pH} 7.4), 100 \mu \mathrm{g} / \mathrm{ml}$ of penicillin, $100 \mu \mathrm{g}$ ) $\mathrm{ml}$ of streptomycin, and $2.5 \mu \mathrm{g} / \mathrm{ml}$ of amphotericin B. Bovine brains, obtained from a local slaughterhouse within $30 \mathrm{~min}$
From the Departments of *Pediatrics and Neurology and tOtorhinolaryngology, University of Michigan, Ann Arbor, MI 48109 .
Received Jan 13, 1983, and in revised form Feb 28, 1983. Accepted for publication Mar 9, 1983.

Address reprint requests to Dr Bowman, Department of Pediatrics, R6060 Kresge II, Ann Arbor, MI 48109. 
utes of death, were transported to the laboratory in iced tissue culture medium. Cortical tissue was cleaned of meninges and superficial blood vessels. Two hundred grams of brain tissue was minced to 1 to $2 \mathrm{~mm}$ cubes, incubated for 3 hours at $37^{\circ} \mathrm{C}$ in $500 \mathrm{ml}$ of medium containing $0.5 \%$ dispase (Boehringer Mannheim, Indianapolis, IN), and collected by centrifugation at $1,000 \mathrm{~g}$ for 10 minutes. The pellets were then suspended in $500 \mathrm{ml}$ of medium, now containing $13 \%$ dextran (Sigma, St Louis, MO; average molecular weight, 60,000). Microvessels were separated from other brain tissue by centrifugation of the suspension at $5,800 \mathrm{~g}$ for 10 minutes. A further 9- to 12-hour treatment of the microvessels with $1 \mathrm{mg} / \mathrm{ml}$ of collagenase/dispase (Boehringer Mannheim) in $20 \mathrm{ml}$ of medium removed the basement membrane and most pericytes. Microvessels were pelleted at $1,000 \mathrm{~g}$ for 10 minutes and suspended in $8 \mathrm{ml}$ of medium. Two milliliters of this suspension was placed on each of four $50 \mathrm{ml}$ Percoll gradients, prepared as described previously [1].

Centrifugation at $1,000 \mathrm{~g}$ for 10 minutes separated the endothelial cells from contaminating debris. The band containing clumps of endothelial cells was removed, diluted with medium, and collected by centrifugation. The cells exhibited 80 to $90 \%$ viability by trypan blue exclusion, and the yield was approximately $2 \times 10^{8}$ viable cells. The cells were seeded onto a fibronectin-coated substrate as previously described [2] and grown in a tissue culture medium consisting of equal parts of nutrient mixture F-12 (GIBCO) and MEM containing $10 \mathrm{mM}$ Hepes ( $\mathrm{pH} 7.4$ ) and $13 \mathrm{mM}$ sodium bicarbonate with $10 \%$ porcine plasma-derived serum (Sterile Systems, Logan, UT). Plasma-derived serum was used to prevent growth of cells not containing FVIII/vWF-AG [2].

\section{Examination}

Identification of cells possessing FVIII/vWF-AG was performed essentially as described by Jaffe and colleagues [9]. Rabbit antiserum to human factor VIII-associated protein was obtained from Behring Diagnostics (La Jolla, CA), and fuorescein-conjugated goat antirabbit IgG was purchased from Cappel Laboratories (Cochranville, PA). This antiserum to human FVIII/vWF-AG cross reacts with bovine antigen and is used to identify endothelial cells derived from bovine aorta [19] and pulmonary artery [20].

For examination with the phase contrast microscope, 25 mm round plastic coverslips (Lux Scientific, Elkhart, IN) were coated with fibronectin to promote cell adhesion, placed in $35 \mathrm{~mm}$ multiwells (Lux Scientific), and seeded with $2 \times 10^{4}$ cells per square centimeter. After the cells achieved confluence (about one week), the coverslips were placed in Sykes-Moore chambers (Bellco, Vineland, NJ). Twenty-onegauge needles connected to syringes with PE-160 tubing were used to pierce the $\mathrm{O}$-ring seal and provide for exchange of media while under observation. A calcium-free medium was prepared by addition of ethyleneglycol-bis-( $\beta$-aminoethyl ether)- $N, N^{\prime}$-tetraacetic acid (EGTA) (Sigma) to $5 \mathrm{mM}$ in Spinner's formulation of MEM (GIBCO), which lacks $\mathrm{Ca}^{+}{ }^{+}$. This solution was buffered to $\mathrm{pH} 7.4$ with $29 \mathrm{mM}$ Hepes. A hypertonic medium was prepared by addition of arabinose (Sigma) to $1.6 \mathrm{M}$ in autoclavable MEM (Flow Labs, Rockville, MD) buffered to pH 7.4 with $29 \mathrm{mM}$ Hepes. Results were compared to a control medium (MEM) with a calcium concentration of $1.8 \mathrm{mM}$.

For scanning electron microscopy the cells were then fixed by treatment with the same medium, now containing glutaraldehyde in a final concentration of $2.5 \%$. After being kept 1 hour at room temperature and overnight at $4{ }^{\circ} \mathrm{C}$, the cells were rinsed three times with phosphate-buffered saline (PBS, $\mathrm{pH} 7.2$ ), postfixed with $1 \%$ osmium terroxide in $0.1 \mathrm{M}$ sodium cacodylate ( $\mathrm{pH} 7.0$ ) for 30 minutes, rinsed an additional three times with distilled water, and air dried. The specimens were then coated with $20 \mathrm{~nm}$ of gold and observed in a scanning electron microscope at $15 \mathrm{kV}$. Although air drying may produce surface artifacts, it ensures the integrity of the lateral associations of cells [3].

For transmission electron microscopy endothelial cells grown on collagen-coated coverslips were rinsed twice with 5 $\mathrm{ml}$ of PBS ( $\mathrm{pH} 7.2$ ) and then fixed with $2.5 \%$ glutaraldehyde in PBS for 15 minutes followed by $2.5 \%$ glutaraldehyde containing $3 \%$ tannic acid (adjusted to $\mathrm{pH} 7.0$ with $5 \mathrm{~N}$ sodium hydroxide). After $\mathbf{4 5}$ minutes the cell layer was washed three times with PBS and postfixed with $1 \%$ osmium tetroxide in $0.1 \mathrm{M}$ sodium cacodylate ( $\mathrm{pH} 7.0)$ for 1 hour. The cell layer was rinsed three times with $0.1 \mathrm{M}$ cacodylate, dehydrated through ethanol, and embedded in Polybed/Araldite (Polysciences, Warrington, PA). Sections were stained with uranyl acetate and lead citrate and viewed in a Philips 400 electron microscope.

For freeze-fracture etching, monolayers grown on fibronectin-coated coverslips were fixed in $2.5 \%$ glutaraldehyde in PBS ( $\mathrm{pH} 7.2$ ) for 1 hour and washed in three changes of PBS. The samples were then placed in $20 \%$ glycerol in PBS for 1 hour. Four $\mathrm{mm}$ discs of the plastic coverslips were cut and placed on specimen carriers [24]. The plastic discs and specimen carriers were frozen rapidly in a slurry of liquid nitrogen, placed in a double-replicating device, and transferred to liquid nitrogen for storage until placed in the freezefracture unit. The monolayers were fractured in a Balzers high vacuum freeze-etch unit at $-115^{\circ} \mathrm{C}$. Platinumshadowed carbon replicas of the fractured faces were coated with $5 \%$ collodion in amyl acetate and cleaned in Clorox bleach for 24 hours. Subsequently the replicas were rinsed in six changes of double distilled water, collected on HEX-460 grids (Polysciences), dipped in amyl acetate for 15 minutes to remove the collodion, and examined in a Philips 400 electron microscope at $60 \mathrm{kV}$.

To carry out transendothelial tracer studies, a support for the cells was fabricated from a $22.2 \times 1.6 \mathrm{~mm}$ Plexiglas disc in which a $9.5 \mathrm{~mm}$ diameter hole had been cut. The hole was beveled to a diameter of $12.7 \mathrm{~mm}$. Nylon mesh $(118 \mu$; Tetko, Elmsford, NY) was attached across the smaller (bottom) side of the hole. The tops of the Plexiglas discs then were glued (Silastic, Dow Corning, Midland, MI) to an $8 \mathrm{~mm}$ piece of polycarbonate tubing $(19 \times 16 \mathrm{~mm})$, forming a sealed chamber. The nylon screen was coated with rat tail collagen prepared as described by Michelopoulis and Pitot [11] and fixed with $4 \%$ glutaraldehyde as described by Cereijido and colleagues [5]. After three washes with $50 \mathrm{ml}$ of sterile PBS, the collagen was treated with $10 \mu \mathrm{g} / \mathrm{cm}^{2}$ human fibronectin for 10 minutes and the collagen-fibronectin matrix was washed an additional 10 times with $50 \mathrm{ml}$ of PBS. Bovine brain endothelial cells were seeded at $4.0 \times 10^{4}$ cells 


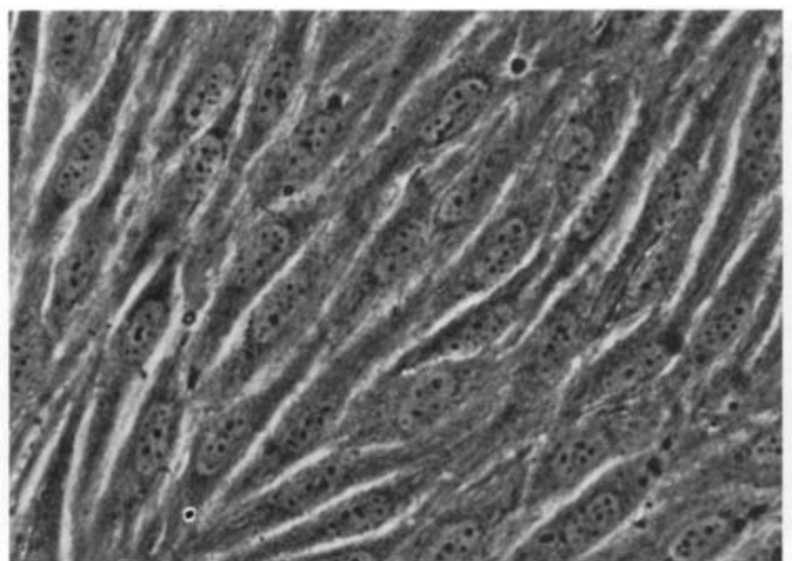

A

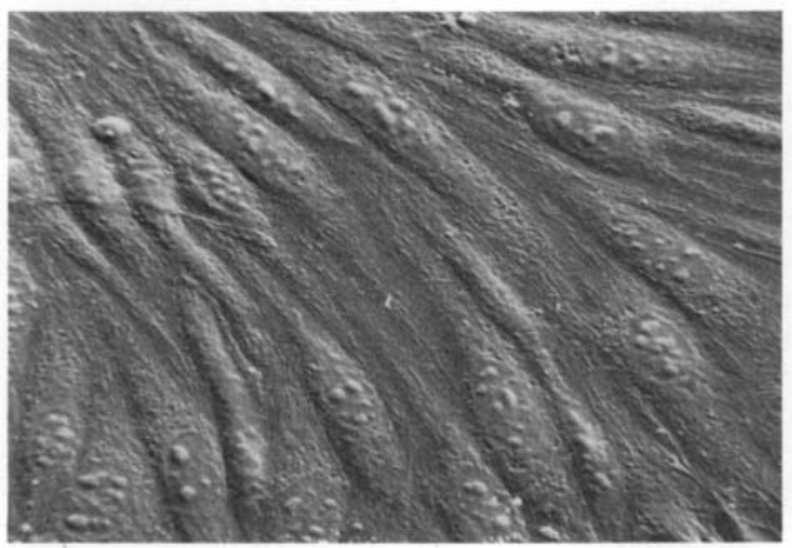

C

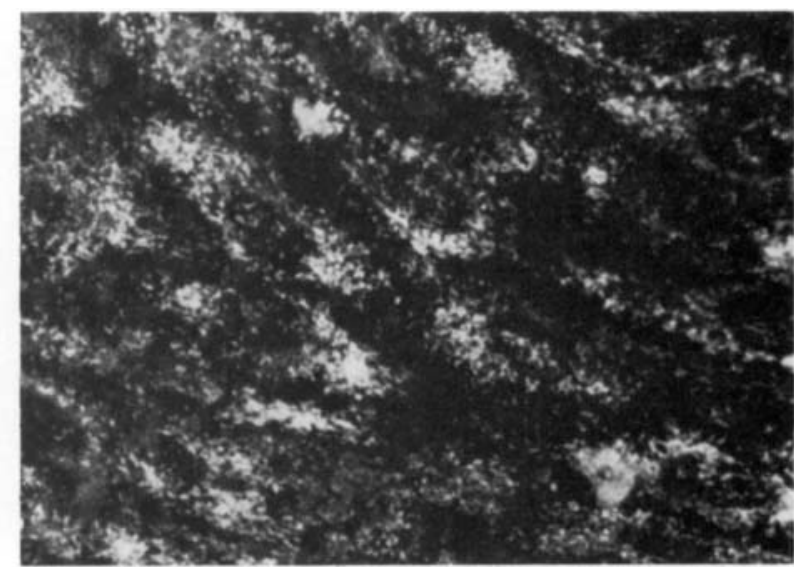

B

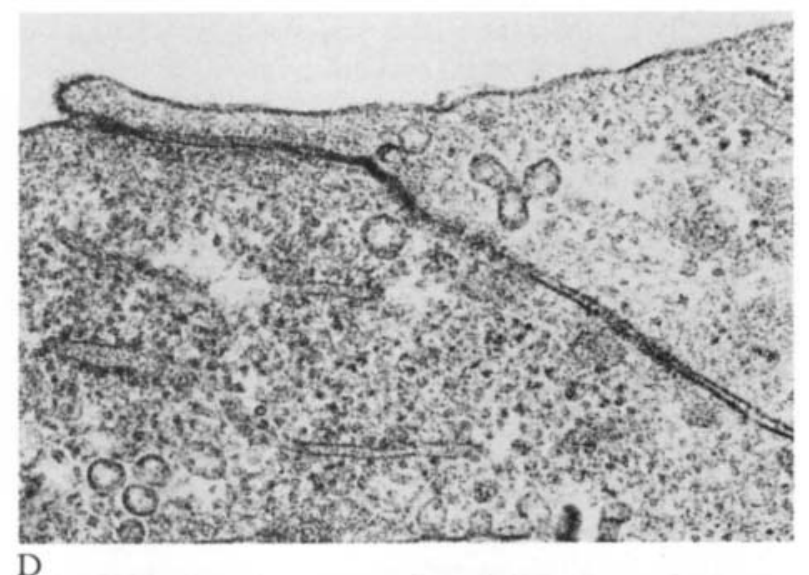

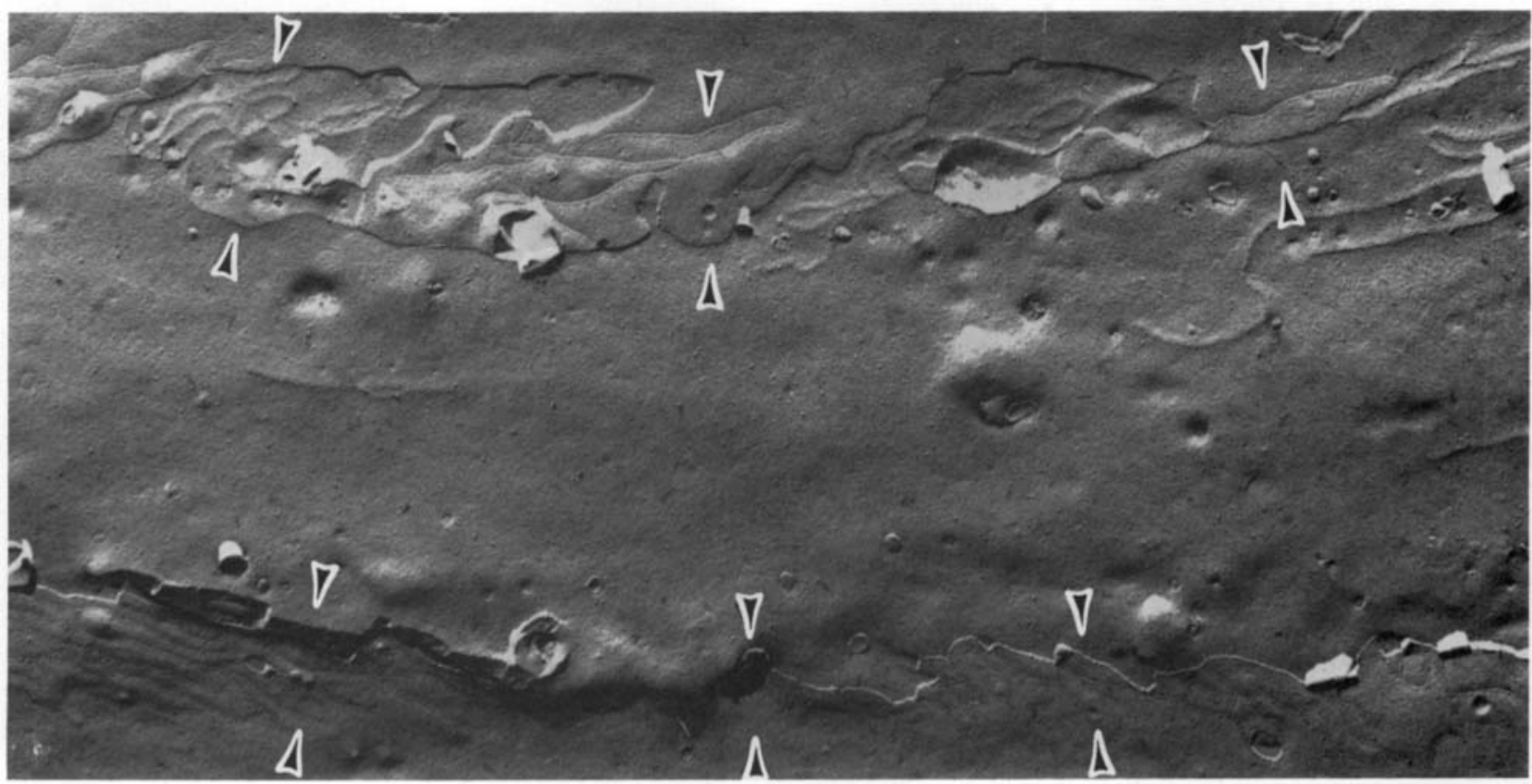

$\mathrm{E}$ 
per square centimeter and allowed to grow and cover the surface for 10 days. Immediately prior to a transport experiment, the chamber containing the cells was affixed to a second piece of polycarbonate tubing with vacuum grease, forming a double-sided chamber. The chamber was then placed in a $35 \mathrm{~mm}$ Petri dish and $10 \mathrm{ml}$ of MEM, containing $29 \mathrm{mM}$ Hepes (pH 7.4), $4.2 \mathrm{mM}$ sodium bicarbonate, and $1.8 \mathrm{mM}$ calcium, was added to the dish. The cells were covered with $1.2 \mathrm{ml}$ of the same medium, and a 5 -minute equilibration period was begun. The fluid in the bottom chamber was in free communication with the surrounding medium, with mixing facilitated by a stirring bar placed in the bottom chamber. After the equilibration period, the medium covering the cells was replaced with an equal volume of medium containing 5 $\mu \mathrm{Ci} / \mathrm{ml}$ sucrose labeled with carbon 14 (New England $\mathrm{Nu}$ clear, Boston, MA). Samples of $0.2 \mathrm{ml}$ were taken from the bottom chamber at various times for measurement of radioactivity by liquid scintillation spectrometry. The volume of the bottom chamber was returned to $10 \mathrm{ml}$ by addition of $0.2 \mathrm{ml}$ of medium after removal of each sample.

The effect of exposure to low calcium on the movement of ${ }^{1 /} \mathrm{C}$-sucrose across the endothelial cell monolayer was studied by adding the calcium-free medium during the 5-minute equilibration period. The effect of an osmotic stress was studied by exposure of the cells for the 5-minute equilibration period to medium containing $1.6 \mathrm{M}$ arabinose. Transcellular movement of ${ }^{14} \mathrm{C}$-sucrose was then measured using normal medium.

\section{Results}

Figure $1 \mathrm{~A}$ illustrates the structure of confluent bovine brain endothelial cells cultured in $10 \%$ porcine plasmaderived serum. The endothelial origin of these cells is supported by the immunofluorescent demonstration of FVIII/vWF-AG (Fig 1B). This antigen is found exclusively in endothelial cells and is widely used as a marker for endothelial cells in culture [8]. As did the endothelial cells from rat brain in our previous cultures $[1]$, the bovine endothelial cells contain angiotensin-converting

Fig 1. Characteristics of cultured brain microvessel endotbelial cells. (A) Phase contrast micrograph of confluent bovine brain endothelial cells. $(\times 525$ before $10 \%$ reduction.) (B) Immunofluorescent demonstration of factor VIII/von Willebrand antigen in cultured bovine brain microvessel endotbelial cells. $(\times 1,200$ before $10 \%$ reduction.) (C) Scanning electron micrograph of cultured bovine brain microvessel endotbelial cells, demonstrating close apposition of cells. ( $\times 700$ before $5 \%$ reduction.) (D) Transmission electron micrograph of cultured bovine brain microvessel endotbelial cells, revealing overlap and a junctional complex between two cells. Only a few pinocytotic vesicles are visible. $(\times 41,000$ before $10 \%$ reduction.) (E) Transmission electron micrograph of platinum-carbon replica of freeze-fractured endothelial monolayer. Arrows demarcate the borders of tight junctions between cells. Complex anastomosing linear arrays of membrane particles are apparent. $(\times 35,000$ before $5 \%$ reduction.) enzyme and form a nonthrombogenic surface (results not shown). Figure $1 \mathrm{C}$ illustrates the structure of cultured brain endothelial cells as observed in the scanning electron microscope. The formation of a continuous sheet of cells with overlap of membranes is evident. That these areas of cell overlap contain junctional complexes was confirmed by transmission electron microscopy (Fig 1D). The nature of these junctions was investigated further by the freeze-fracture technique. Figure $1 \mathrm{E}$ illustrates that the region between endothelial cells is characterized by a continuous network of complex anastomosing membrane particle arrays. This pattern is similar to that seen in the tight junctions of brain capillaries in vivo [21]. In addition, the endothelial cells in culture have few pinocytotic vesicles, a further similarity to their in vivo counterpart (see Fig 1D).

Satisfied that primary cultures of brain microvessel cells possess many of the properties that are known to have important barrier functions in vivo, we investigated the barrier formed in vitro by a monolayer of these cells. To observe the effects on structure of experimental manipulation, cells were grown to confluence on fibronectin-coated coverslips, mounted in a perfusion chamber, and observed by phase microscopy. After the cells were observed and photographed under normal conditions, test media were perfused through the chamber and serial observations of structural changes were documented. In each case morphological changes developed rapidly and were maximal after less than 5 minutes of exposure to the test medium. The chambers were then reperfused with normal culture medium and the cultures returned to the $37^{\circ} \mathrm{C}$ incubator. Observations were made for the next 24 hours to document reversibility of the cellular changes produced by the treatment. Separate coverslips were incubated under control and test conditions and then prepared for scanning electron microscopy either after the exposure to experimental conditions or 6 hours after return to normal culture conditions.

Figure $2 \mathrm{~A}$ illustrates the effect on endothelial cultures of a 2-minute exposure to calcium-free medium. The retraction of cells from one another is apparent. Scanning electron microscopic examination (Fig 2B) revealed a loss of the ability to form continuous sheets. That these cells survived this treatment and reestablished contact after being returned to a calciumcontaining medium is illustrated by scanning electron microscopy in Figure 2C (6 hours after treatment).

The effect of $1.6 \mathrm{M}$ arabinose on the cultured endothelial cell monolayer at the phase microscopic level is revealed in Figure $2 \mathrm{D}$. A reduction in phase contrast imaging indicates removal of water from the cells. Because this treatment does not result in cell separation, the junctional complexes must be relatively intact. Scanning electron microscopy revealed craters in or 


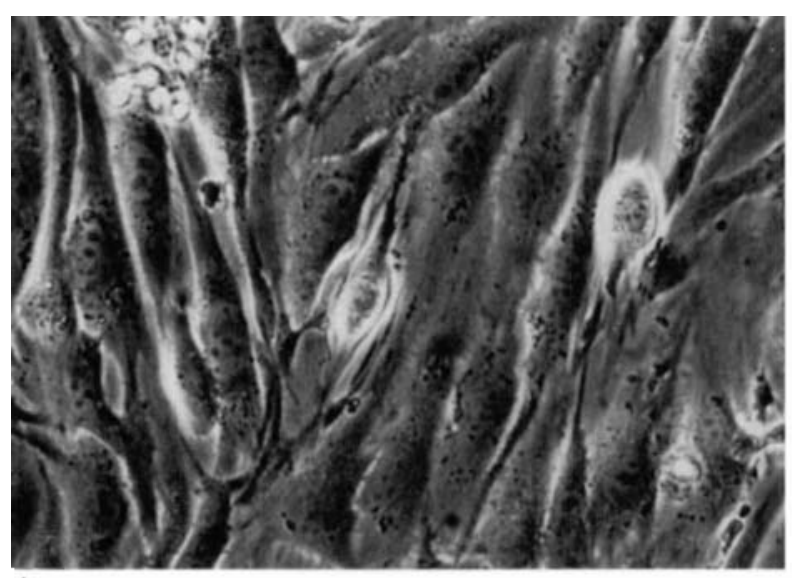

A

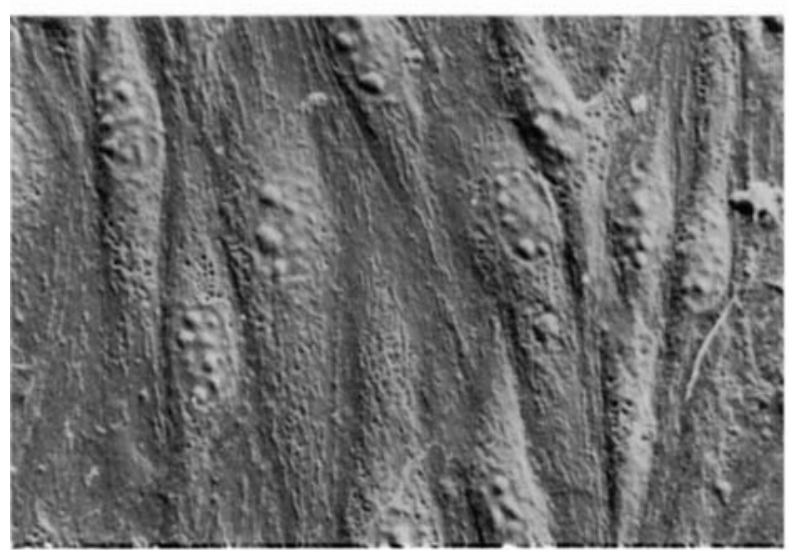

C

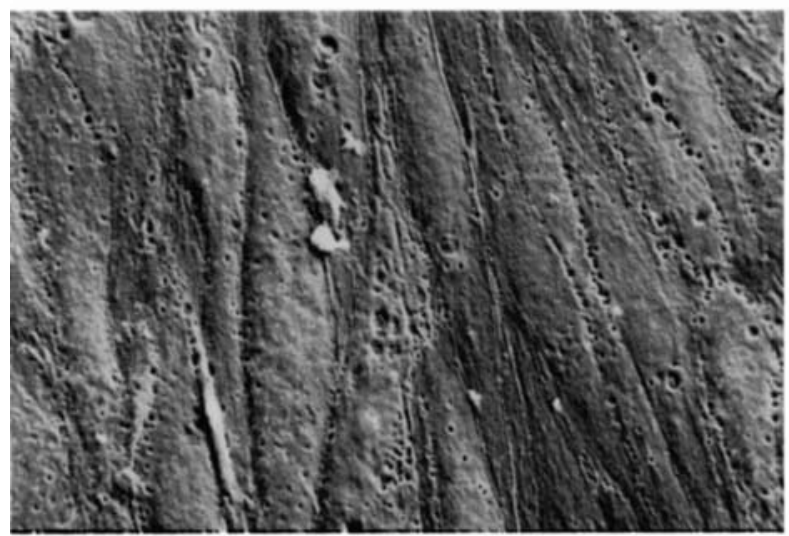

$\mathrm{E}$

Fig 2. Morphological effects of calcium removal or arabinose treatment on cultured brain microvessel endothelial cells. (A) Phase contrast micrograph of cells treated for 2 minutes with $\mathrm{Ca}^{++}$-free medium containing $5 \mathrm{mM} E G T A$, demonstrating retraction of cells from one anotber. ( $\times 600$ before $10 \%$ reduction.) (B) Scanning electron micrograph of cells after calcium removal, revealing a substantial separation of the cells and exposure of the underlying coverslip. $(\times 740$ before $10 \%$ reduction.) (C) Scanning electron micrograph of cells 6 bours after their return to calcium-containing medium, demonstrating the restoration of cell contacts.

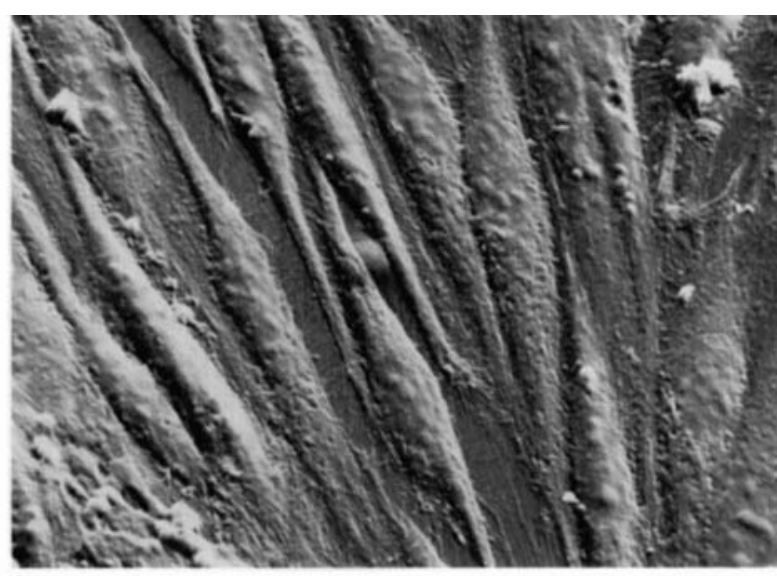

B

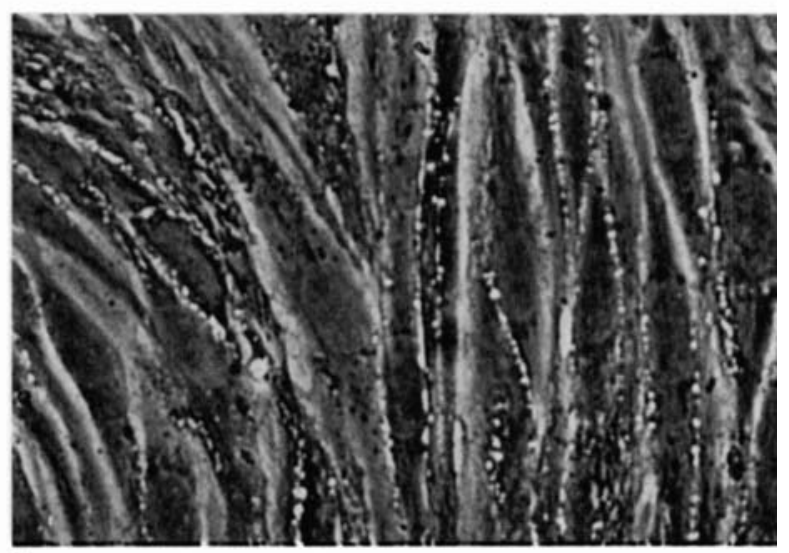

D

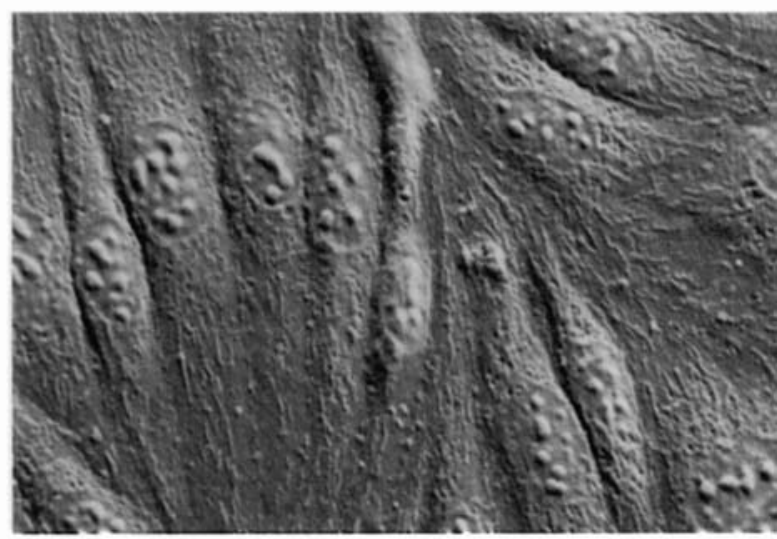

$\mathrm{F}$

( $\times 850$ before $10 \%$ reduction.) (D) Phase contrast micrograph of cells treated for 2 minutes with $1.6 \mathrm{M}$ arabinose, revealing regions of clearing in or near the junctional contacts. In addition. nuclear and cytoplasmic structures are indistinct. $(\times 625$ before $10 \%$ reduction.) (E) Scanning electron micrograpb of arabinosetreated cells, showing craters in or near the junctional contacts between cells. ( $\times 780$ before $10 \%$ reduction.) (F) Sianning electron micrograph of arabinose-treated cells 6 bours after return to an isotonic medium, demonstrating restoration of normal structure. $(\times 850$ before $10 \%$ reduction.) 


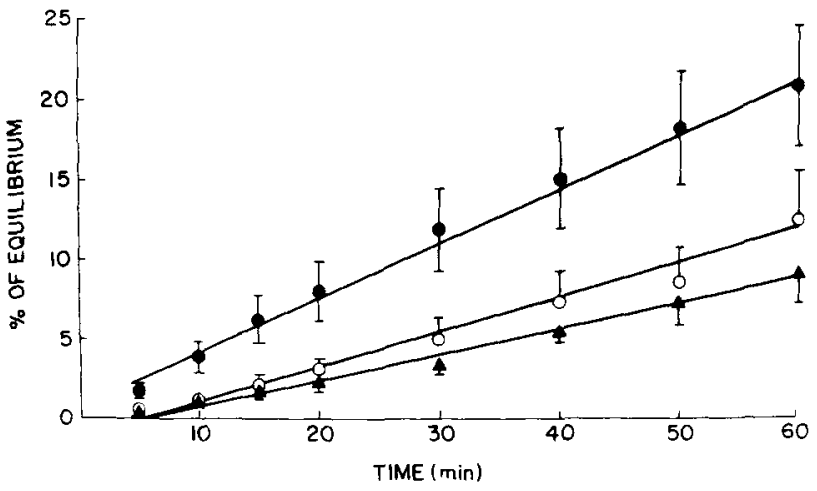

Fig 3. Permeability effects of calcium removal or arabinose treatment on cultured brain microvessel endotbelial cells. The amount of labeled sucrose that has moved across the monolayer is shown as a percentage of the calculated equilibrium value. Points represent the means \pm standard errors of the mean for four to six experiments at each time point. The lines drawn through the experimental points were obtained using linear regression analysis of all data within the control (triangles), calcium-free (filled circles) or arabinose-treated (open circles) groups. To compare the effect of treatment on the rate of transcellular sucrose movement, the slopes of the experimental groups were compared to the slope of the control group using a single-tailed t test. Values abtained (control, $0.160 \pm 0.017 ;$ calcium free, $0.347 \pm 0.044$; arabinose treated, $0.221 \pm 0.029)$ indicate a bighly significant $(\mathrm{p}<$ $0.005)$ increase in the rate of sucrose movement following calcium removal and a more modest increase ( $\mathrm{p}<0.05)$ following arabinose treatment.

near the junctional complexes (Fig 2E). Although these sites may provide a pathway for the movement of sucrose across the monolayer (to be discussed), scanning electron microscopy does not permit a determination of whether they represent true transcellular channels or, possibly, fluid-filled vesicles that collapsed during air drying. Figure $2 \mathrm{~F}$ demonstrates that endothelial cells treated for 5 minutes with $1.6 \mathrm{M}$ arabinose regain normal structure 6 hours after return to normal medium.

We examined the effects of these experimental manipulations on the movement of an extracellular marker across cultured brain capillary endothelium. Figure 3 presents the findings concerning the movement of ${ }^{14} \mathrm{C}$-sucrose across a monolayer of endothelial cells grown on collagen-coated nylon mesh. The monolayer of cells provides a barrier to the diffusion of sucrose, as indicated by the control findings. Exposure of the monolayer to calcium-free media for 5 minutes increased the rate of movement of sucrose by $120 \%$. In contrast, exposure of the monolayer to $1.6 \mathrm{M}$ arabinose for 5 minutes increased sucrose movement by only $40 \%$.

\section{Discussion}

The ability to isolate and culture endothelial cells derived from brain microvessels provides a new way to investigate cellular properties and metabolic reactions important to the function of the blood-brain barrier [1, $6,14,16,22]$. The cells used in this investigation were prepared from capillaries isolated from bovine brain. Special care was taken to purify the endothelial cells from possible contaminating cells such as pericytes, smooth muscle cells, and glial cells. Because of the potential for contamination by these other cell types, we established the presence of several specific markers of endothelium in our cultured cells. The markers included FVIII/vWF-AG, angiotensin-converting enzyme, and the production of a nonthrombogenic surface. In addition to these general endothelial properties, the cultured cells also formed frequent tight junctions and contained few pinocytotic vesicles (see Fig 1). These results indicate that the cells in vitro retain features responsible for formation of the bloodbrain barrier in vivo.

In this investigation we studied the effect of two experimental manipulations on the integrity of the barrier formed by cultured brain endothelial cells. Removal of ionized calcium from the extracellular fluid is known to result in separation of tight junctions in epithelial tissues [10]. We found nearly complete separation and retraction of the cultured endothelial cells under these conditions (see Fig 2). Consistent with the wide separation of the endothelial cells, there was a marked increase in the movement of sucrose across the monolayer (see Fig 3). As in the epithelial tissues, junctional contact was reestablished by return of the cells to a physiological concentration of calcium.

The permeability of the blood-brain barrier in vivo is enhanced for several hours by brief infusion of hypertonic arabinose through the carotid artery [17]. This technique is used to increase the uptake of polar substances that normally are excluded in brain and is of considerable interest as a method for permitting the entry of drugs, proteins, and other organic molecules $[12,13]$. We found a distinctive change in the structure of brain capillary endothelial cells treated with arabinose at the concentration used in vivo (see Fig 2). Unlike the major disruption of barrier continuity found after removal of calcium, a more limited change in perijunctional structure was produced by the hypertonic treatment. Not surprisingly, this trearment resulted in a smaller increase in the transcellular movement by sucrose than did the exposure to calcium-free medium (see Fig 3). Again, the morphological reaction was reversible, and the continuity of the cell layer was reestablished within 6 hours of return to normal culture medium. No lasting toxic effect was noted from this brief hypertonic treatment.

Brain microvessel endothelial cells in tissue culture form a barrier that responds to experimental manipulation. The integrity and permeability of this barrier can be monitored using morphological and tracer tech- 
niques. This new system should provide a useful model for study of blood-brain barrier function and reaction to injury.

Supported by Grants HL26840 and ES02380 from the National Institutes of Health, and by Grant 1-706 from the March of Dimes Birth Defects Foundation. Dr Betz is the recipient of an Established Investigator Award from the American Heart Association.

The authors thank Rekha Bhise, Diane Ar, Janet Mullen, and Otho Artis II for technical assistance.

\section{References}

1. Bowman PD, Betz AL, At D, et al: Primary culture of capillary endotheliurn from rat brain. In Vitro 17:353-362, 1981

2. Bowman PD, Betz AL, Goldstein GW: Primary culture of microvascular endothelial cells from bovine retina. In Vitro 18:626-632, 1982

3. Boyde A, Weiss RA, Vesely P: Scanning electron microscopy of cells in culture. Exp Cell Res 71:313-324, 1972

4. Broadwell RD, Salcman M: Expanding the definition of the blood-brain barrier to protein. Proc Natl Acad Sci USA 78:7820-7824, 1981

5. Cereijido M, Robbins ES, Dolan WJ, et al: Polarized monolayers formed by epithelial cells on permeable and translucent support. J Cell Biol 77:853-880, 1978

6. DeBault LE, Kahn LE, Frommes SP, Cancilla PA: Cerebral microvessels and derived cells in tissue culture: isolation and preliminary characterization. In Vitro 15:473-487, 1979

7. Goldstein GW, Bowman PD, Betz AL: Reversible separation of tight junctions in cultured brain capillary endothelial cells. Pediatr Res 16:335A, 1982

8. Jaffe EA: Endothelial cells and the biology of factor VIII. N Engl J Med 296:377-383, 1977

9. Jaffe EA, Hoyer LW, Nachman RL: Synthesis of antihemophilic factor by cultured endothelial cells. J Clin Invest 52:2757-2764, 1973

10. Meldolesi J, Castiglioni G, Parma R, et al: $\mathrm{Ca}^{++}$-dependent disassembly and reassembly of occluding junctions in guinea pig pancreatic acinar cells. J Cell Biol 79:156-172, 1978
11. Michelopoulis G, Pitot $\mathrm{H}$ : Primary culture of parenchymal liver cells on collagen membranes. Exp Cell Res 94:70-78, 1975

12. Neuwelt EA, Barranger JA, Brady RO, et al: Delivery of hexosaminidase $A$ to the cerebrum after osmotic modification of the blood-brain barrier. Proc Natl Acad Sci USA 78:5838-5841, 1981

13. Neuwelt EA, Diehl JT, Vu LH, et al: Monitoring of methotrexate delivery in patients with malignant brain tumors after osmotic blood-brain barrier disruption. Ann Intern Med 94:449-454, 1981

14. Panula P, Joo F, Rechardt L: Evidence for the presence of viable endothelial cells in cultures derived from dissociated rat brain. Experientia 34:95-97, 1978

15. Petito CK: Early and late mechanisms of increased vascular permeability following experimental cerebral infarction. J Neuropathol Exp Neurol 38:222-234, 1979

16. Phillips $P$, Kumar $P$, Kumar $S$, Waghe $M$ : Isolation and characterization of endothelial cells from rat and $c 0 w$ brain white matter. J Anat 129:261-272, 1979

17. Rapoport SI, Fredericks WR, Ohno K, Pettigrew KD: Quantitative aspects of reversible osmotic opening of the blood-brain barrier. Am J Physiol 238:R421-R431, 1980

18. Reese TS, Karnovsky MJ: Fine structural localization of a bloodbrain barrier to exogenous peroxidase. J Cell Biol 34:207-217, 1967

19. Ryan US, Clements E, Habliston D, Ryan JW: Isolation and culture of pulmonary artery endothelial cells. Tissue Cell 10:535-554, 1978

20. Schwartz SM: Selection and characterization of bovine aortic endothelial cells. In Vitro 14:966-980, 1978

21. Shivers RR: The blood-brain barrier of a reptile, Anolis carolinensis: a freeze-fracture study. Brain Res 169:221-230, 1979

22. Spatz M, Bembry J, Dodson RF, et al: Endothelial cell cultures derived from isolated cerebral microvessels. Brain Res 191:577-582, 1980

23. Westergaard E: The blood-brain barrier to horseradish peroxidase under normal and experimental conditions. Acta Neuropathol (Berl) 39:181-187, 1977

24. Yee AG, Fischbach GD, Karnovsky MJ: Clusters of intramembranous particles on cultured myotubes at sites that are highly sensitive to acerylcholine. Neurobiology 75:3004-3008, 1978 